\title{
Peer-review: Let's imitate the lawyers!
}

Citation for published version (APA):

Jelicic, M., \& Merckelbach, H. L. G. J. (2002). Peer-review: Let's imitate the lawyers! Cortex, 38, 406-407. https://doi.org/10.1016/S0010-9452(08)70669-5

Document status and date:

Published: 01/01/2002

DOI:

10.1016/S0010-9452(08)70669-5

Document Version:

Publisher's PDF, also known as Version of record

\section{Please check the document version of this publication:}

- A submitted manuscript is the version of the article upon submission and before peer-review. There can be important differences between the submitted version and the official published version of record.

People interested in the research are advised to contact the author for the final version of the publication, or visit the DOI to the publisher's website.

- The final author version and the galley proof are versions of the publication after peer review.

- The final published version features the final layout of the paper including the volume, issue and page numbers.

Link to publication

\footnotetext{
General rights rights.

- You may freely distribute the URL identifying the publication in the public portal. please follow below link for the End User Agreement:

www.umlib.nl/taverne-license

Take down policy

If you believe that this document breaches copyright please contact us at:

repository@maastrichtuniversity.nl

providing details and we will investigate your claim.
}

Copyright and moral rights for the publications made accessible in the public portal are retained by the authors and/or other copyright owners and it is a condition of accessing publications that users recognise and abide by the legal requirements associated with these

- Users may download and print one copy of any publication from the public portal for the purpose of private study or research.

- You may not further distribute the material or use it for any profit-making activity or commercial gain

If the publication is distributed under the terms of Article $25 \mathrm{fa}$ of the Dutch Copyright Act, indicated by the "Taverne" license above, 


\title{
PEER-REVIEW: LET'S IMITATE THE LAWYERS!
}

\author{
Marko Jelicic and Harald Merckelbach \\ (Department of Experimental Psychology, University of Maastricht, The Netherlands)
}

As noted by Della Sala and Grafman in their Editorial, the traditional peerreview process has many drawbacks. In this comment, we would like to emphasize one particular problem of peer review, namely how reviewers handle findings that are incompatible with their own viewpoints. Speculating as to why it took several years before his ideas on the architecture of human memory were accepted by cognitive psychologists, Tulving (1999) noted that “(...) we scientists love to hate new ideas (...) and we routinely resist facts that do not fit into whatever comfortable framework we have managed to adopt (p. 12)." If this is correct, it would mean that journal referees exhibit a "confirmation bias", such that they tend to favour manuscripts describing results in line with their own theoretical position.

Is there evidence for confirmation bias in scientists? Chinn and Brewer (1993) showed that when science students are confronted with findings contradicting their beliefs, they tend to discount such findings in various ways. Sometimes "anomalous" results are simply ignored or placed in abeyance, other times the results are rejected, excluded from the domain of the theory at stake, or reinterpreted in such a way that the original theory is retained. Occasionally, when repeatedly exposed to data that contradict their ideas, students may change their theoretical positions.

It appears that confirmation bias is not limited to students. Chinn and Brewer offer many convincing examples from the history of science demonstrating that scientists also have a propensity to discount data in order to protect their viewpoints. Interestingly, some authors have warned against the deleterious effects of confirmation bias among scientists. Greenwald et al. (1986), for instance, argued that the tendency of researchers to ignore or reject data incompatible with their own viewpoints may obstruct scientific progress. These authors describe how confirmation bias among social psychologists hindered revision of the theory on the so-called sleeper effect. The sleeper effect pertains to the delayed persuasive effect of a communication accompanied by a discounting cue (i.e., information indicating that the communication is untrustworthy). This phenomenon was discovered in the late 1940s, and while research in the early 1970s showed that the sleeper effect only took place under certain circumstances, it was not until the mid 1980s that the original theory was modified. Greenwald et al. provide evidence that researchers in the 1970s did not revise their theoretical ideas on the sleeper effect because their confirmation bias led them to ignore failed replications. Of course, it would be naïve to think that confirmation bias only occurs in social psychology.

We have reason to believe that reviewers also suffer from confirmation bias.

Cortex, (2002) 38, 406-407 
In the past, we have, independently of one another, submitted manuscripts describing research that conflicted with received theoretical viewpoints. Although, in our view, the work reported in these manuscripts did not contain serious methodological flaws, we had great difficulty getting it published. We suspect that many authors have had similar experiences. Finally, what can be done against confirmation bias of journal reviewers? It is safe to assume that researchers who are prominent advocates of a certain theory are especially prone to such bias. Perhaps, then, editors should not invite them to review manuscripts describing findings incompatible with their view. On the other hand, prominent advocates are often the ones with special expertise and therefore it would be unwise to exclude them from the review procedure. So here is a more immodest proposal: let's imitate the judicial system. Authors submit their manuscripts together with a plea of a non-affiliated counsel explaining why the work warrants publication. Editors appoint prosecutors whose task it is to detect serious errors in the manuscript. The editor-in-chief together with two associated editors serve as judges and come up with a final verdict. This procedure makes biases explicit and the guilty author can always move for a new trial at another journal.

\section{REFERENCES}

CHINN CA and BREwer WF. The role of anomalous data in knowledge acquisition: A theoretical framework and implications for science instruction. Review of Educational Research, 63: 1-49, 1993.

Greenwald AG, Pratkanis AR, Leippe MR and Baumgardner MH. Under what conditions does theory obstruct research progress? Psychological Review, 93: 216-229, 1986.

Tulving E. Study of memory: Processes and systems. In Foster JK and Jelicic M (Eds), Memory: Systems, Process, or Function? Oxford: Oxford University Press, 1999, pp. 11-30.

Marko Jelicic, Department of Experimental Psychology, University of Maastricht, P.O. Box 616, 6200 MD Maastricht, The Netherlands. E-mail: m.jelicic@psychology.unimaas.nl 